\title{
Contrasting effects of the polychaetes Marenzelleria viridis and Nereis diversicolor on benthic metabolism and solute transport in sandy coastal sediment
}

\author{
Erik Kristensen $^{1, *}$, Tanja Hansen ${ }^{1}$, Matthieu Delefosse ${ }^{1}$, Gary T. Banta ${ }^{2}$, \\ Cintia O. Quintana ${ }^{1}$ \\ ${ }^{1}$ Institute of Biology, University of Southern Denmark, Campusvej 55, 5230 Odense M, Denmark \\ ${ }^{2}$ Department of Environmental, Social and Spatial Change, Roskilde University, Universitetsvej 1, 4000 Roskilde, Denmark
}

\begin{abstract}
The contrasting effects of the invasive Marenzelleria viridis and the native Nereis diversicolor on benthic metabolism, partitioning of reaction pathways and distribution of inorganic porewater ( $\mathrm{C}$ and $\mathrm{N}$ ) solutes in homogenized sandy sediment were investigated experimentally over a period of 1 mo. The 2 species were studied separately and in combination to observe possible effects and interactions. Benthic $\mathrm{O}_{2}$ uptake and total $\mathrm{CO}_{2}\left(\mathrm{TCO}_{2}\right)$ release were affected similarly by $M$. viridis, $N$. diversicolor and the two in combination, with roughly a doubling after 1 to 2 wk compared to defaunated sediment. Sulfate reduction after $1 \mathrm{mo}$, on the other hand, was more than twice as high in sediment inhabited by $M$. viridis alone than in any other treatment, even when combined with $N$. diversicolor. Denitrification estimated from benthic $\mathrm{TCO}_{2}$ release, porewater reaction stoichiometry and nutrient fluxes was largely unaffected by the presence of fauna. Accordingly, the partitioning of reaction pathways after 1 mo revealed that $M$. viridis stimulated sulfate reduction at the expense of aerobic respiration. Most of the oxygen uptake in $M$. viridis sediment was apparently due to enhanced oxidation resulting from an upward drifting front of sulfide as indicated by low redox and the appearance of Beggiatoa sp. near the surface. Porewater solute profiles showed that $M$. viridis was capable of stronger and deeper irrigation than $N$. diversicolor despite $\sim 10$ times higher burrow ventilation by the latter species. This effect was caused by percolation of return water in the deep ( $>20 \mathrm{~cm}$ ) I- or J-shaped burrows of $M$. viridis compared to the flushing of the more shallow (6 to $8 \mathrm{~cm}$ ) U- shaped burrows of $N$. diversicolor. A replacement of the native $N$. diversicolor with the invasive $M$. viridis as the dominant burrow-dwelling polychaete in shallow coastal sediments will probably affect the biogeochemical functioning and ecological stability of the ecosystem. Among other things, organisms tolerant to sulfide are likely to be favored at the expense of more sensitive species.
\end{abstract}

KEY WORDS: Invasive species - Porewater irrigation · C and N solutes · Reaction pathways Sulfate reduction

Resale or republication not permitted without written consent of the publisher

\section{INTRODUCTION}

Benthic metabolism and distribution of porewater solutes in soft bottom sediment are controlled by the balance between reaction processes associated with organic matter decay and transport conditions (Jørgensen \& Boudreau 2001, Jahnke et al. 2005). This bal- ance can be changed dramatically by the presence of bioturbating infauna (Aller 1982, Kristensen 2001). It is known that burrow-dwelling infauna may enhance the capacity for bulk benthic metabolism up to $300 \%$ (Kristensen 2000). Mechanisms responsible for this faunal induced enhancement of microbial metabolism and capacity for organic matter degradation in sediments 
include particle reworking and burrow ventilation (Aller 1982, Aller \& Aller 1998, Papaspyrou et al. 2007). Model considerations have shown that exposure of anoxic sediment to oxygen in ventilated burrows enhances carbon oxidation significantly and to a higher extent than particle reworking (Kristensen \& Holmer 2001).

Ventilation by burrowing macrofauna disrupts the diffusional gradients and strongly affects the transport conditions within sediments. The associated porewater irrigation facilitates the exchange of solutes across the sediment-water interface and influences the distribution of dissolved reactants and products of early diagenetic reactions (Meile \& Van Cappellen 2003, Meysman et al. 2006). Faunal enhancement of solute transport can exceed molecular diffusion by as much as an order of magnitude (Kristensen \& Kostka 2005). The actual extent of the enhancement is, however, strongly dependent on the species composition and functional structure of the infaunal community present (Kristensen 2000, Aller 2001).

The 2 burrow-dwelling polychaetes Marenzelleria viridis (Spionidae) and Nereis diversicolor (Nereididae) are common inhabitants of Danish coastal sediments with a high potential for affecting sediment biogeochemistry. $M$. viridis is an invasive species that originates from North America and was first reported in Europe around 1980 in the Forth Estuary, Scotland (McLusky et al. 1993). It rapidly spread along the mainland coasts of the North Sea (Essink \& Kleef 1988, 1993) and reached the western Baltic Sea in 2004 (Bastrop \& Blank 2006). An almost simultaneous spread of the sibling species Marenzelleria neglecta occurred in the southern and central Baltic Sea (Sikorski \& Bick 2004). A salinity of $\sim 10$ seems to delimit the distribution of these 2 species in the Baltic Sea, with $M$. viridis restricted to salinities above and $M$. neglecta to salinities below this level. The transition zone is located around the Island of Rügen, Germany (Blank et al. 2008).

Marenzelleria viridis is a surface deposit-feeder that ventilates its 30 to $40 \mathrm{~cm}$ deep vertical I- or J-shaped burrows in sandy sediment by ciliary (George 1966, Essink \& Kleef 1988) and possibly muscular (Quintana et al. 2011) action. Strong evidence indicates that $M$. viridis has the capacity to outcompete the native Nereis diversicolor in certain shallow areas (Essink \& Kleef 1993, Kotta et al. 2006). N. diversicolor is a common native species along marine and brackish coasts all over Europe (Maltagliati et al. 2006). It is a surface deposit-feeder or suspension-feeder that builds 6 to $10 \mathrm{~cm}$ deep U- or Y-shaped burrows in sand and muddy-sand (Esselink \& Zwarts 1989, Riisgård 1991). The burrows are ventilated vigorously by undulatory body movements (Kristensen \& Kostka 2005).
Effects of Marenzelleria viridis on sediment biogeochemistry are poorly known and the only studies available on Marenzelleria effects are from the central and northern Baltic Sea (Karlson et al. 2005, Hietanen et al. 2007, Viitasalo-Frösén et al. 2009), where primarily the sibling species $M$. neglecta or $M$. arctia occur in finegrained muddy sediments. However, Quintana et al. (2007) found that $M$. viridis in Danish waters prefers shallow sandy sediment. These authors also found that $M$. viridis has low particle reworking and considerable irrigation capacity. Nevertheless, its ventilation activity is not very intense as indicated from the lack of an oxidized halo around burrows. Thus, adult individuals are reported to ventilate their blind-ended burrows at an average rate of $<4 \mathrm{ml} \mathrm{h}^{-1}$ (Quintana et al. 2011). Much of the return water apparently percolates slowly through the sediment back to the surface and increases the exchange of solutes across the sedimentwater interface (Quintana et al. 2007). The lack of studies on Marenzelleria viridis in relation to sediment biogeochemistry is surprising considering its rapid spread in recent years and current high abundance in European coastal areas. Even more so when its potential for outcompeting the native Nereis diversicolor is taken into account. The impact of the latter species on sediment biogeochemistry is well investigated (e.g. Hansen \& Kristensen 1998, Kristensen \& Mikkelsen 2003, Papaspyrou et al. 2006). N. diversicolor ventilates its burrows actively at rates of 80 to $190 \mathrm{ml} \mathrm{h}^{-1}$ (Kristensen \& Kostka 2005). The burrow walls are surrounded by a several $\mathrm{mm}$ thick oxidized halo with intense microbial activity affecting $\mathrm{C}, \mathrm{N}$ and $\mathrm{S}$ biogeochemistry (Nielsen et al. 2004).

The aim of this study was to highlight contrasting effects of the invasive Marenzelleria viridis and the native Nereis diversicolor on benthic fluxes of $\mathrm{O}_{2}$, total $\mathrm{CO}_{2}\left(\mathrm{TCO}_{2}\right)$ and dissolved inorganic nitrogen (DIN), as well as sulfate reduction and solute transport in sandy sediment from Odense Fjord, Denmark. We hypothesize that replacement of $N$. diversicolor by the deep burrowing $M$. viridis in sandy coastal areas (1) modifies solute profiles by enhanced transport deep in sediments, and (2) alters the balance of biogeochemical pathways responsible for organic carbon oxidation.

\section{MATERIALS AND METHODS}

Sampling site and sample handling. Sandy sediment and specimens of Marenzelleria viridis and Nereis diversicolor were sampled in the shallow (mean depth of $2.2 \mathrm{~m}$ ) Odense Fjord estuary on the island of Fyn, Denmark. Historical data from Odense Fjord has shown a rapidly increasing abundance of $M$. viridis 
from its first scattered occurrence in 2002 to its presence along $60 \%$ of the coastline at densities up to $3000 \mathrm{~m}^{-2}$ in 2010 (M. Delefosse et al. unpubl. data). Sampling was conducted during March 2008 at Bregnør Bay $\left(55.48118^{\circ} \mathrm{N}, 10.61002^{\circ} \mathrm{E}\right)$ in the outer part of the fjord. The sampling site is normally covered by 20 to $50 \mathrm{~cm}$ water, but periods of air exposure can occur depending on the strength and direction of the winds. Freshwater discharge from streams causes the salinity to vary from 15 to 25 (Fyns Amt 2003). Water temperature was $10^{\circ} \mathrm{C}$ during sampling.

The sediment was wet-sieved through a $1 \mathrm{~mm}$ mesh on location to remove larger particles and macrofauna. Specimens of Nereis diversicolor and Marenzelleria viridis were carefully collected during the sieving procedure. Intact and healthy individuals selected for the experiments were kept in darkened Petri dishes containing seawater at a salinity of 20 and a temperature of $15^{\circ} \mathrm{C}$ until use in the experiment.

Experimental set up. The sieved sediment was homogenized in the laboratory and transferred to 27 Plexiglas core liners (33 cm long and $8 \mathrm{~cm}$ diameter) leaving $10 \mathrm{~cm}$ of overlying water. The cores were placed with open tops in two $90 \mathrm{l}$ tanks containing a common reservoir with seawater from the sampling site at $15^{\circ} \mathrm{C}$ (salinity of 20) and maintained in $12 \mathrm{~h}$ light/12 h dark cycles. The cores were illuminated vertically by a greenhouse lamp (Philips, Son-T Agro $400 \mathrm{~W})$ at an incident intensity of $250 \mu \mathrm{mol} \mathrm{m} \mathrm{m}^{-2} \mathrm{~s}^{-1}$ on the sediment surface to stimulate microphytobenthic growth as a food source for sediment organisms during the experiment. All cores were wrapped in aluminum foil covering the sediment phase to avoid photosynthesis along the walls of the cores. Water circulation inside the cores was assured by an external rotating magnet (60 rpm) driving internal magnetic stirring bars placed in the overlying water phase of each core. Worms were transferred to the sediment cores after a $2 \mathrm{~d}$ stabilization period at a natural Odense Fjord density of 1200 individuals (ind.) $\mathrm{m}^{-2}$ (M. Delefosse et al. unpubl. data) as follows: (1) 6 Marenzelleria viridis ind. (total of 0.7 to $1.0 \mathrm{~g}$ wet wt) to each of 6 replicate cores (M-cores); (2) 6 Nereis diversicolor ind. (1.1 to $1.5 \mathrm{~g}$ wet wt) to each of 6 replicate cores (N-cores); and (3) 3 ind. of $M$. viridis ( 0.4 to $0.9 \mathrm{~g}$ wet wt) and 3 ind. of $N$. diversicolor ( 0.4 to $0.8 \mathrm{~g}$ wet wt) to each of 6 replicate cores (MN-cores). The remaining 9 cores were kept as defaunated controls (C-cores). Triplicates of C-cores were sliced for determination of the initial sediment conditions and sulfate reduction on the day of worm addition (Day 0). Initial fluxes were measured $4 \mathrm{~d}$ later (Day 4) and subsequently once every week for $3 \mathrm{wk}$ (Day 11, 18 and 25). From each treatment, 3 cores were sacrificed on Day 16 and the remaining cores on Day 31 for determination of sediment characteristics, sul- fate reduction, redox (only Day 31) and porewater solutes.

Benthic fluxes. Fluxes of $\mathrm{O}_{2}, \mathrm{TCO}_{2}\left(\mathrm{CO}_{2}+\mathrm{HCO}_{3}{ }^{-}+\right.$ $\mathrm{CO}_{3}{ }^{2-}$ ), $\mathrm{NH}_{4}{ }^{+}$and $\mathrm{NO}_{2}{ }^{-}+\mathrm{NO}_{3}{ }^{-}$(here denoted $\mathrm{NO}_{3}{ }^{-}$) across the sediment-water interface were determined from $3.5 \mathrm{~h}$ dark incubations initiated at the end of the dark period. The cores were sealed gas tight with rubber stoppers during flux incubations while maintaining water stirring. Fluxes were calculated from the concentration difference between start and end water samples. $\mathrm{O}_{2}$ was analyzed immediately after sampling by the standard Winkler technique (Parsons et al. 1984) and never decreased $<60 \%$ of air saturation. $\mathrm{TCO}_{2}$ samples were preserved with saturated $\mathrm{HgCl}_{2}$ in $5 \mathrm{ml}$ glass Exetainers and stored at $5^{\circ} \mathrm{C}$ until analysis by the flow injection/diffusion cell technique (Hall \& Aller 1992). Subsamples for $\mathrm{NH}_{4}{ }^{+}$and $\mathrm{NO}_{3}{ }^{-}$were stored frozen $\left(-20^{\circ} \mathrm{C}\right)$ in $20 \mathrm{ml}$ plastic vials. Samples were prefiltered through GF/F-filters before analysis on a Lachat Quickchem 8500 Flow Injection Analyzer according to the protocols of Bower \& Holm-Hansen (1980) for $\mathrm{NH}_{4}{ }^{+}$and Armstrong et al. (1967) for $\mathrm{NO}_{3}{ }^{-}$.

Sulfate reduction. Sulfate reduction (SR) was measured on Day 0, 16 and 31. One subcore (internal diameter: $2.6 \mathrm{~cm}$ ) was taken from each of 3 experimental cores before slicing for porewater solutes. The subcores were injected with $5 \mu \mathrm{l}{ }^{35} \mathrm{~S}_{-} \mathrm{SO}_{4}{ }^{2-}$ (60 kBq) through silicone-filled ports at $1 \mathrm{~cm}$ intervals down to $19 \mathrm{~cm}$ (only $11 \mathrm{~cm}$ on Day 0) and left for incubation in darkness at $15^{\circ} \mathrm{C}$ for $\sim 6 \mathrm{~h}$. The cores were subsequently sectioned into $1-\mathrm{cm}$ depth intervals to $2 \mathrm{~cm}$, and $2 \mathrm{~cm}$ intervals to $18 \mathrm{~cm}$ (the sections $10-12$ and $14-16 \mathrm{~cm}$ were discarded). The sediment slices were fixed in $0.5 \mathrm{M}$ zinc acetate and stored frozen until analysis by the one-step distillation procedure of Fossing \& Jørgensen (1989). The total reduced inorganic sulfur pool (TRIS) was determined spectrophotometrically (Cline 1969) as part of the same procedure.

Sediment characteristics. Experimental cores were sectioned into the same intervals as for SR. Subsamples were taken from each sediment slice for porosity (i.e. water content $\times$ wet density) and organic matter content, while samples for grain size analysis were only taken from the upper $1 \mathrm{~cm}$. All worms observed during slicing were recovered and counted. Subsamples for grain size analysis were wet sieved through a Wentworth series of sieves $(1000,500,250,125,63 \mu \mathrm{m}$ mesh). The fractions that were retained by sieves and passed through the $63 \mu \mathrm{m}$ sieve were dried before weighing and grain size analysis was conducted according to Bale \& Kenny (2005). Wet density $\left(\mathrm{g} \mathrm{cm}^{-3}\right)$ was determined as the weight of a known volume of sediment. Water content was determined as weight 
loss after drying for $20 \mathrm{~h}$ at $105^{\circ} \mathrm{C}$, and organic content was determined as weight loss of dried sediment after combustion for $6 \mathrm{~h}$ at $520^{\circ} \mathrm{C}$ according to Kristensen \& Andersen (1987).

Porewater analysis. Porewater from sediment subsamples of each slice was extracted by centrifugation at $1500 \mathrm{rpm}$ for $10 \mathrm{~min}$ in double centrifuge tubes containing GF/F filters. Subsamples from the porewater were taken for $\mathrm{TCO}_{2}, \mathrm{SO}_{4}{ }^{-}$and $\mathrm{NH}_{4}{ }^{+}$analysis. $\mathrm{TCO}_{2}$ was preserved with $20 \mu \mathrm{l}$ saturated $\mathrm{HgCl}_{2}$ in $1.5 \mathrm{ml}$ glass vials and stored at $5^{\circ} \mathrm{C}$ until analysis as mentioned above. $\mathrm{SO}_{4}^{-}$was analyzed by ion chromatography (Dionex ICS-2000) and normalized to chloride concentrations according to Martin \& Banta (1992). Samples for $\mathrm{NH}_{4}{ }^{+}$and $\mathrm{NO}_{3}{ }^{-}$were stored frozen until analysis as mentioned above.

Redox. Vertical redox (Eh) profiles were determined on intact cores before the final slicing with a needle Redox electrode (RD-N) (Unisense A/S) connected to a Calomel reference electrode and monitored on an Impo Electronic type $1510 \mathrm{pH} / \mathrm{mV}$-meter. The electrode was inserted into the sediment in steps of $2.5 \mathrm{~mm}$ in the upper $1.5 \mathrm{~cm}$, and thereafter every $5 \mathrm{~mm}$ down to $5 \mathrm{~cm}$. The Eh signal was allowed to stabilize for $1 \mathrm{~min}$ at each depth before the reading was noted. Five profiles were measured from $\mathrm{C}$ - and $\mathrm{N}$-cores, while 6 profiles were obtained from $\mathrm{M}$-cores (3 within visible Beggiatoa sp. mats and 3 outside mats). No profiles were made in $\mathrm{MN}$-cores.

Statistical analysis. Flux data were analyzed using a 2-way ANOVA to test for effects of treatment and time. Sediment profiles were analyzed using depth integrated values. Significant differences were further investigated using a Tukey's post hoc multiple comparison between means or Dunnet's test for comparison with control means. Data were tested for normality (Kolmogorov-Smirnov test) and homogeneity of variance (Levene's test). The significance level is 0.05 unless otherwise stated.

\section{RESULTS}

\section{Sediment appearance during final slicing}

The sediment consisted of well-sorted sand with a mean grain size of $265 \pm 17 \mu \mathrm{m}(\mathrm{n}=3)$ and a silt + clay fraction of $2.48 \pm 0.02 \%(\mathrm{n}=3)$. Porosity and organic content were almost constant with depth and similar among cores. Porosity ranged from 0.28 to 0.30 and organic content varied from 0.55 to $0.72 \%$ dry wt among cores.

Visually, C- and M-cores had $<0.5 \mathrm{~cm}$ thick, brownish, oxidized surface layer, whereas this layer in $\mathrm{N}$ and $\mathrm{MN}$-cores was up to $1 \mathrm{~cm}$ thick with patches asso- ciated to Nereis diversicolor burrow openings extending to depths of 3 to $4 \mathrm{~cm}$. The sediment appeared grayish-black in color underneath the oxidized layer. Up to $2 \mathrm{~mm}$ thick microalgal mats were observed on the sediment surface of $\mathrm{C}$-cores at the end. Microalgae were only observed occasionally on the surface of the sediment in $\mathrm{M}$ - and $\mathrm{N}$-cores. The surface of M-cores was visually characterized by Marenzelleria viridis faeces and burrow openings, and the occurrence of several white Beggiatoa sp. patches (maximum area of $\sim 2 \mathrm{~cm}^{2}$ ). $M$. viridis burrows had a diameter of $\sim 2 \mathrm{~mm}$ and extended all the way to the bottom of the cores $(\sim 20 \mathrm{~cm})$, and the worms were always recovered deeper than $8 \mathrm{~cm}$. The openings of $N$. diversicolor burrows protruded a few $\mathrm{mm}$ above the surface in $\mathrm{N}$-cores. $\mathrm{N}$. diversicolor individuals were always found in the lower part of the U-shaped burrows at a depth of 4 to $6 \mathrm{~cm}$. Burrows of $N$. diversicolor were surrounded by a $\mathrm{mm}$ thick oxidized halo. No such oxidized zone was evident around $M$. viridis burrows at any time. The MN-cores shared the characteristics of M- and $\mathrm{N}$-cores with surface deposited faeces of $M$. viridis, protruded $N$. diversicolor burrow openings, occasional microalgae, and Beggiatoa sp. patches.

The survival of Marenzelleria viridis at Day 16 was $56 \pm 10$ and $89 \pm 38 \%$ in $\mathrm{M}$ - and MN-cores, respectively, while $78 \pm 10$ and $100 \pm 33 \%$ of the introduced Nereis diversicolor was recovered in $\mathrm{N}$ - and $\mathrm{MN}$ cores, respectively, at that time. Survival at Day 31 decreased slightly, reaching $56 \pm 10$ and $44 \pm 19 \%$ for $M$. viridis and $61 \pm 10$ and $89 \pm 19 \%$ for $N$. diversicolor in the respective treatments.

\section{Benthic solute fluxes}

$\mathrm{O}_{2}$ was taken up and $\mathrm{TCO}_{2}$ released by the sediment throughout the experiment (Table 1). There were no significant interactions among treatments and time for $\mathrm{O}_{2}$ and $\mathrm{TCO}_{2} \cdot \mathrm{O}_{2}$ uptake was constant with time and always lowest in C-cores (15 to $17 \mathrm{mmol} \mathrm{m} \mathrm{m}^{-2} \mathrm{~d}^{-1}$ ). Mand $\mathrm{N}$-cores had significantly 20 to $40 \%$ higher $\mathrm{O}_{2}$ uptake than C-cores on Day 4, increasing to $\sim 100$ to $120 \%$ on Day 11, with no further change to the end (Fig. 1A). No such temporal trend was evident for MNcores that always had significantly $~ 100 \%$ higher rates than C-cores. $\mathrm{TCO}_{2}$ release from the sediment showed the same pattern as $\mathrm{O}_{2}$ uptake, but the changes reaching 50 to $70 \%$ higher rates in faunated than in C-cores after Day 4 were not significant (Fig. 1B). The respiratory quotient ( $\mathrm{RQ}=\mathrm{TCO}_{2} / \mathrm{O}_{2}$ flux ratio) ranged between 3 and 6 , and showed a marginally significant decreasing trend with time ( $p=0.07$, data not shown).

There was an apparent uptake of $\mathrm{NH}_{4}{ }^{+}$in $\mathrm{C}$-cores and release in the faunated cores (Table 1), particu- 
Table 1. Sediment-water flux of $\mathrm{O}_{2}$, total carbon oxidation $\left(\mathrm{TCO}_{2}\right)$, $\mathrm{NH}_{4}{ }^{+}$and $\mathrm{NO}_{3}{ }^{-}$in treatments $\mathrm{C}, \mathrm{M}, \mathrm{N}$ and $\mathrm{MN}$. Fluxes were measured weekly over a $25 \mathrm{~d}$ period. Negative flux: uptake by sediment. Values are means $\pm \mathrm{SE}(\mathrm{n}=3)$. Cores without fauna $(\mathrm{C})$, with Marenzelleria viridis $(\mathrm{M})$, with Nereis diversicolor $(\mathrm{N})$, and mixture of $M$. viridis and $N$. diversicolor $(\mathrm{MN})$

\begin{tabular}{|c|c|c|c|c|}
\hline Core & Day 4 & Day 11 & Day 18 & Day 25 \\
\hline \multicolumn{5}{|c|}{$\mathrm{O}_{2}\left(\mathrm{mmol} \mathrm{m}^{-2} \mathrm{~d}^{-1}\right)$} \\
\hline $\mathrm{C}$ & $-16.7 \pm 3.6$ & $-14.9 \pm 1.0$ & $-17.6 \pm 0.1$ & $-16.8 \pm 0.8$ \\
\hline M & $-23.8 \pm 2.0$ & $-32.2 \pm 1.2$ & $-36.6 \pm 4.0$ & $-39.1 \pm 2.6$ \\
\hline $\mathrm{N}$ & $-20.5 \pm 3.1$ & $-28.6 \pm 0.1$ & $-33.1 \pm 3.2$ & $-33.9 \pm 1.7$ \\
\hline $\mathrm{MN}$ & $-32.0 \pm 1.8$ & $-32.4 \pm 3.5$ & $-32.3 \pm 3.5$ & $-36.9 \pm 2.0$ \\
\hline \multicolumn{5}{|c|}{$\mathrm{TCO}_{2}\left(\mathrm{mmol} \mathrm{m}^{-2} \mathrm{~d}^{-1}\right)$} \\
\hline $\mathrm{C}$ & $95.9 \pm 3.7$ & $76.0 \pm 15.1$ & $64.5 \pm 4.4$ & $64.2 \pm 6.0$ \\
\hline M & $99.4 \pm 4.5$ & $125.1 \pm 17.9$ & $100.9 \pm 24.1$ & $110.9 \pm 18.6$ \\
\hline $\mathrm{N}$ & $83.1 \pm 19.5$ & $99.9 \pm 13.9$ & $98.8 \pm 29.0$ & $100.9 \pm 30.8$ \\
\hline $\mathrm{MN}$ & $100.0 \pm 28.0$ & $131.4 \pm 24.9$ & $89.5 \pm 9.7$ & $109.6 \pm 14.5$ \\
\hline \multicolumn{5}{|c|}{$\mathrm{NH}_{4}{ }^{+}\left(\mathrm{mmol} \mathrm{m}{ }^{-2} \mathrm{~d}^{-1}\right)$} \\
\hline $\mathrm{C}$ & $-7.0 \pm 0.9$ & $-8.7 \pm 1.2$ & $-3.2 \pm 1.3$ & $-3.5 \pm 4.4$ \\
\hline M & $8.3 \pm 2.5$ & $6.5 \pm 0.9$ & $6.9 \pm 1.0$ & $8.7 \pm 3.2$ \\
\hline $\mathrm{N}$ & $4.9 \pm 1.8$ & $2.4 \pm 2.7$ & $2.1 \pm 0.5$ & $5.9 \pm 0.3$ \\
\hline $\mathrm{MN}$ & $4.6 \pm 3.0$ & $13.2 \pm 3.1$ & $8.3 \pm 0.8$ & $8.4 \pm 4.1$ \\
\hline \multicolumn{5}{|c|}{$\mathrm{NO}_{3}^{-}\left(\mathrm{mmol} \mathrm{m}{ }^{-2} \mathrm{~d}^{-1}\right)$} \\
\hline $\mathrm{C}$ & $4.8 \pm 0.5$ & $0.7 \pm 0.2$ & $0.9 \pm 0.2$ & $0.6 \pm 0.5$ \\
\hline M & $-0.3 \pm 0.7$ & $-0.8 \pm 0.2$ & $-0.3 \pm 0.1$ & $-1.0 \pm 1.3$ \\
\hline $\mathrm{N}$ & $-0.3 \pm 0.3$ & $-0.6 \pm 0.3$ & $0.4 \pm 0.6$ & $0.3 \pm 0.3$ \\
\hline MN & $-1.5 \pm 1.5$ & $0.3 \pm 0.2$ & $0.6 \pm 0.2$ & $0.4 \pm 0.5$ \\
\hline
\end{tabular}

larly those containing Marenzelleria viridis, but with no significant difference through time. $\mathrm{NO}_{3}^{-}$was released from $\mathrm{C}$-cores at a rate corresponding to $69 \%$ of the $\mathrm{NH}_{4}{ }^{+}$uptake on Day 1, and 8 to $27 \%$ subsequently (Table 1). The faunated cores showed no specific pattern in $\mathrm{NO}_{3}^{-}$flux, and rates were rarely significantly different from 0 .

\section{Sulfate reduction}

SR at Day 0 increased from $\sim 90 \mathrm{nmol} \mathrm{cm}^{-3} \mathrm{~d}^{-1}$ in the upper $2 \mathrm{~cm}$ of the sediment to a constant level of

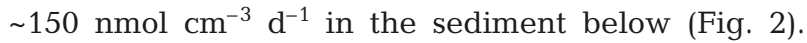
C-cores showed an SR pattern in the upper $6 \mathrm{~cm}$ that was similar on both Day 16 and 31: a relatively high level of $\sim 200 \mathrm{nmol} \mathrm{cm}{ }^{-3} \mathrm{~d}^{-1}$ in the top $\mathrm{cm}$ followed by

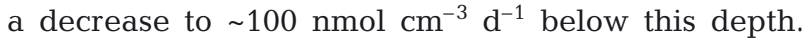
While SR remained at $\sim 100 \mathrm{nmol} \mathrm{cm}{ }^{-3} \mathrm{~d}^{-1}$ down to at least $16-18 \mathrm{~cm}$ in these cores on Day 16 (Fig. 2A), a progressive decrease occurred below $6 \mathrm{~cm}$ depth on Day 31, reaching zero at $16-18 \mathrm{~cm}$ (Fig. 2B). M-, Nand MN-cores down to $12-14 \mathrm{~cm}$ showed SR profiles at a level of 100 to $150 \mathrm{nmol} \mathrm{cm} \mathrm{c}^{-3} \mathrm{~d}^{-1}$ at Day 16 that were constant with depth and not significantly different from each other and C-cores. Below this depth, $\mathrm{SR}$ in M-cores increased significantly to $240 \mathrm{nmol}$ $\mathrm{cm}^{-3} \mathrm{~d}^{-1}$ at $16-18 \mathrm{~cm}$ (Fig. 2A). N- and MN-cores maintained roughly the same profiles on Day 31, while the entire profile in $\mathrm{M}$-cores reached a significantly higher level of 200 to $270 \mathrm{nmol} \mathrm{cm} \mathrm{cm}^{-3}$ throughout the sediment column (Fig. 2B).

The concentration of TRIS was low in all treatments and ranged between 5 and $11 \mathrm{nmol} \mathrm{S} \mathrm{cm}^{3}$ in an unpredictable pattern (Fig. 3A,B). There was an increasing trend with time in all treatments, indicating an accumulation of reducing equivalents in the form of precipitated sulfide. The sulfide accumulation ranged from 10 to $40 \mathrm{mmol} \mathrm{S} \mathrm{m}^{-2} \mathrm{~d}^{-1}$ among treatments, with highest rates during the first $16 \mathrm{~d}$.

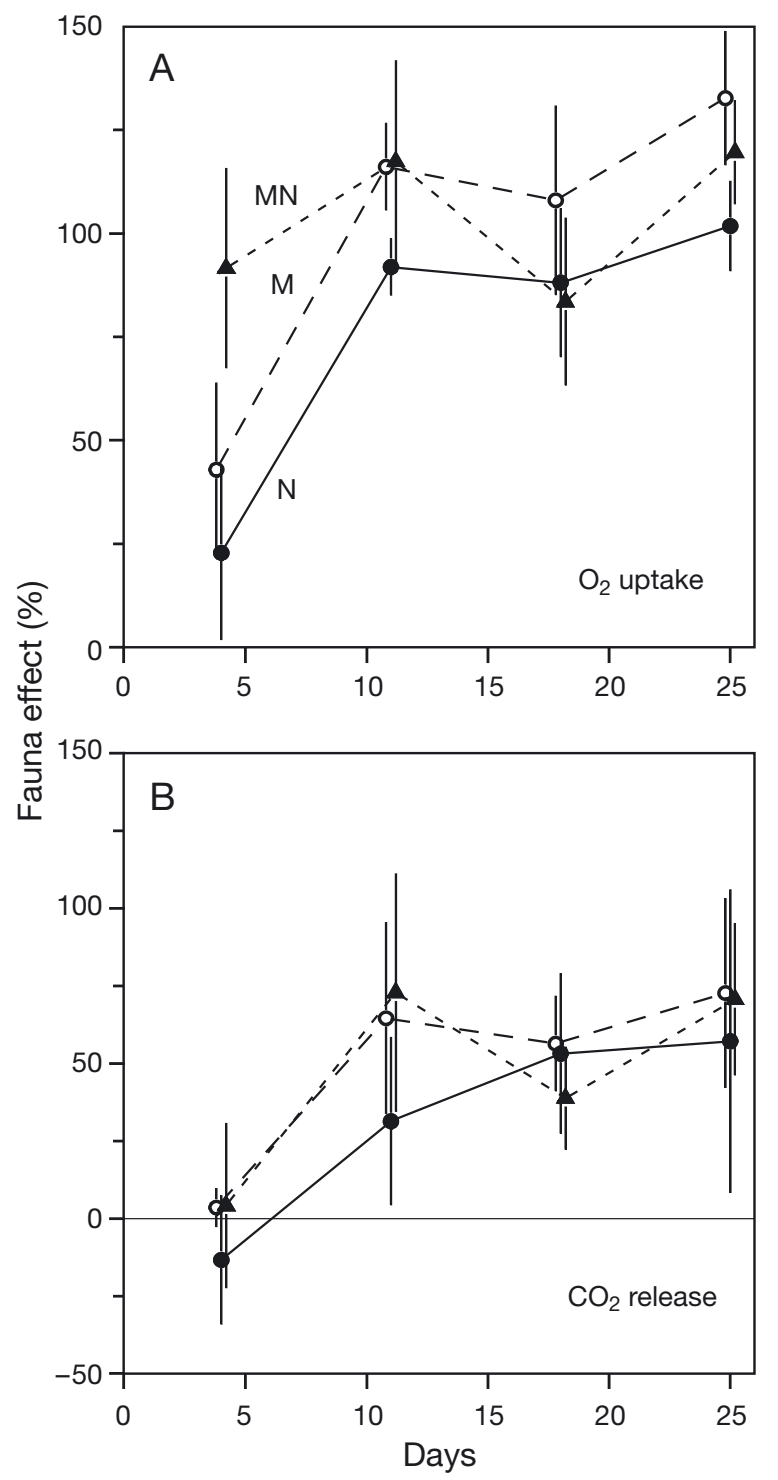

Fig. 1. Enhancement of (A) $\mathrm{O}_{2}$ and (B) total $\mathrm{CO}_{2}$ flux across the sediment-water interface over time in $\mathrm{M}-, \mathrm{N}-$ and $\mathrm{MN}-$ sediment relative to $C$-sediment. Values: mean \pm SE $(n=3)$. Cores: without fauna (C), with Marenzelleria viridis (M), with Nereis diversicolor $(\mathrm{N})$, and mixture of $M$. viridis and $N$. diversicolor $(\mathrm{MN})$ 


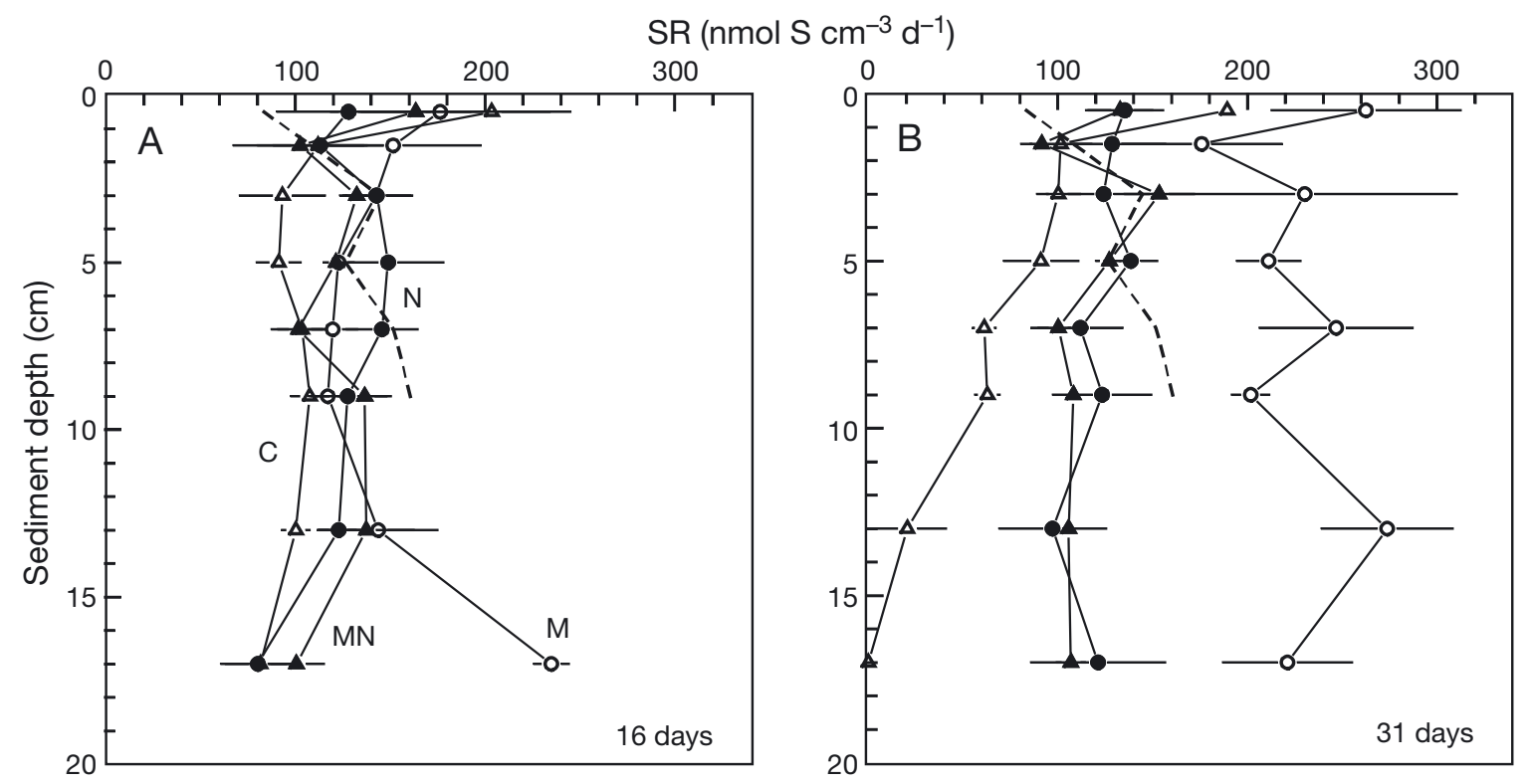

Fig. 2. Vertical profiles of sulfate reduction (SR) in C-, M-, N- and MN-sediment at (A) Day 16 and (B) Day 31. Values: mean \pm SE $(\mathrm{n}=3)$. Broken lines: initial (Day 0) SR. See Fig. 1 for core definitions

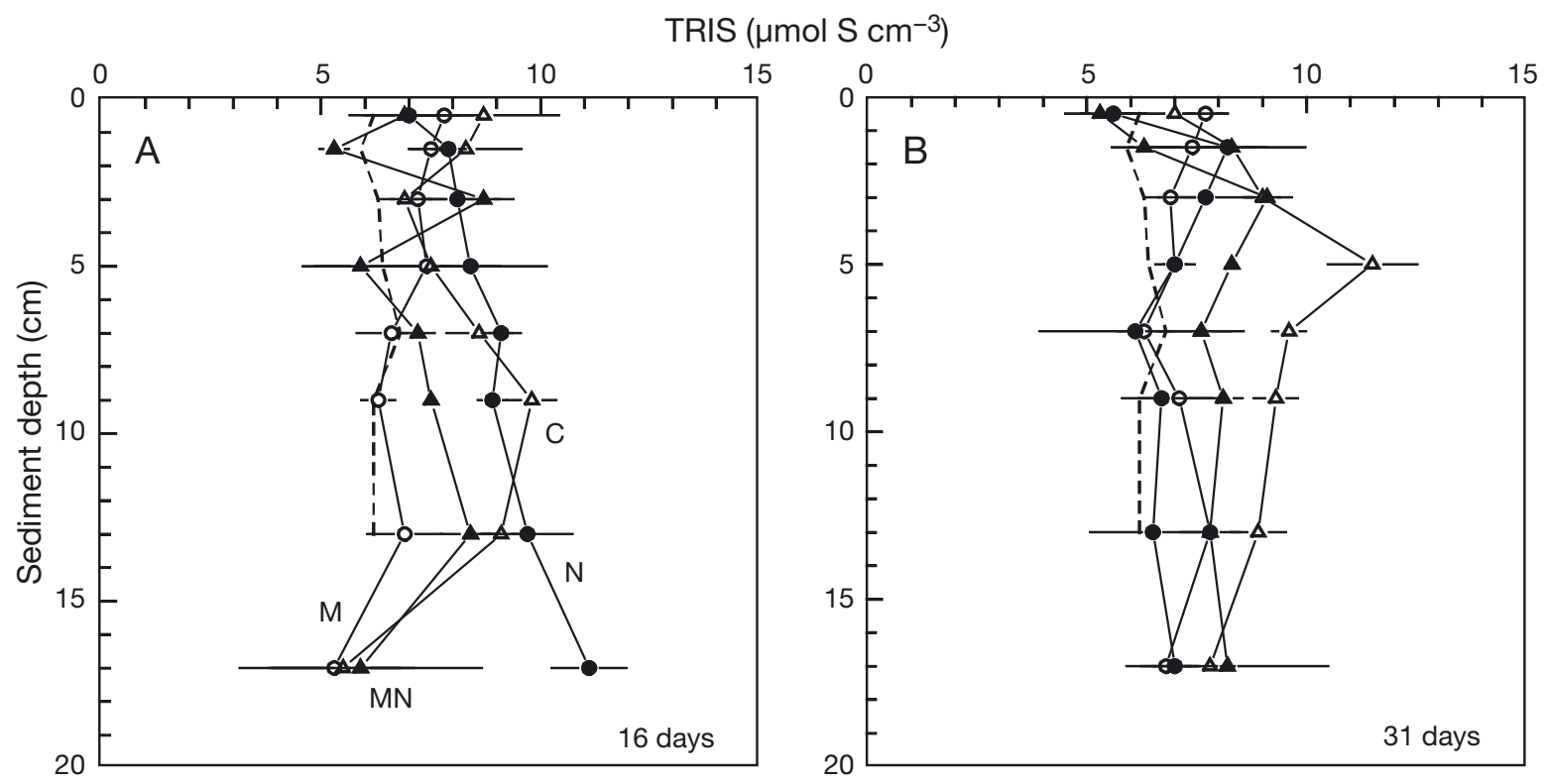

Fig. 3. Vertical profiles of total reduced inorganic sulfur (TRIS) in C-, M-, N- and MN-sediment at (A) Day 16 and (B) Day 31. Values: mean \pm SE $(n=3)$. Broken lines: initial (Day 0) TRIS. See Fig. 1 for core definitions

\section{Porewater solutes}

Initial porewater $\mathrm{TCO}_{2}$ increased rapidly from $\sim 2.5 \mathrm{mM}$ in the overlying water to a constant level of $\sim 10 \mathrm{mM}$ at 1 to $2 \mathrm{~cm}$ depth and below. A similar increase was observed near the surface to $6 \mathrm{~cm}$ depth in sandy C-cores on Days 16 and 31, followed by a less steep increase below that depth, reaching 21 and $26 \mathrm{mM}$ at 16-18 $\mathrm{cm}$ depth, respectively (Fig. 4A,B).
C-cores were significantly different from the faunated cores throughout the examined depth interval. $\mathrm{TCO}_{2}$ in $\mathrm{M}$-cores barely increased beyond the overlying water level in the upper $10 \mathrm{~cm}(<5 \mathrm{mM})$ and only increased slightly below this depth, reaching 8 and $9 \mathrm{mM}$ at $16-18 \mathrm{~cm}$ depth on Day 16 and 31, respectively. N-cores also exhibited low $\mathrm{TCO}_{2}$ near the surface, but only to $2-4 \mathrm{~cm}$ depth. Below this depth, $\mathrm{TCO}_{2}$ increased steadily to 16 and $20 \mathrm{mM}$ at $16-18 \mathrm{~cm}$ on 

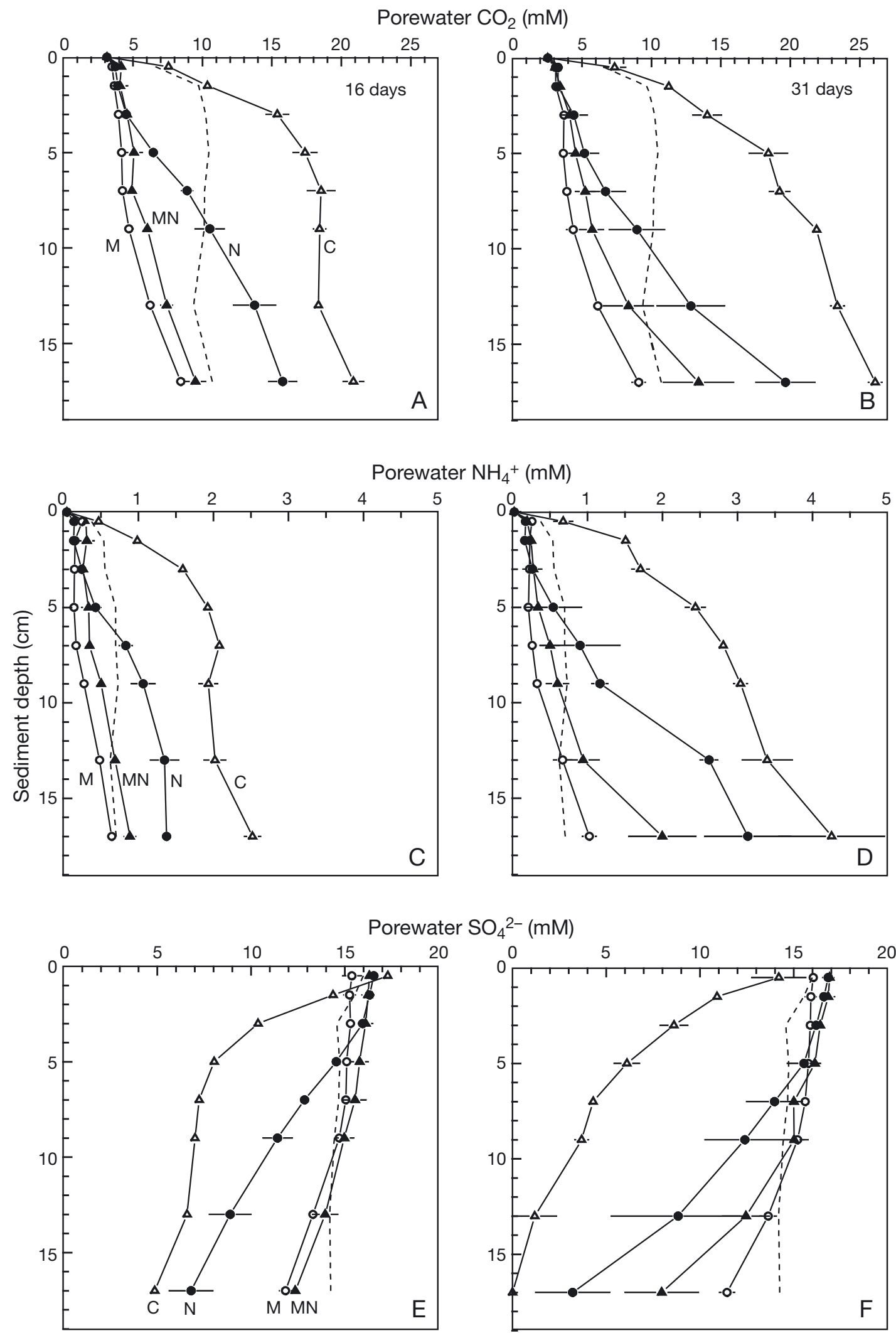

Fig. 4. Vertical profiles of porewater solutes in C-, M-, N- and MN-sediment. Total $\mathrm{CO}_{2}, \mathrm{NH}_{4}{ }^{+}$and $\mathrm{SO}_{4}{ }^{2-}$ at $(\mathrm{A}, \mathrm{C}, \mathrm{E}) \mathrm{Day} 16$, and $(\mathrm{B}, \mathrm{D}, \mathrm{F})$ Day 31, respectively. Values: mean $\pm \mathrm{SE}(\mathrm{n}=3)$. Broken lines: initial (Day 0) profiles. See Fig. 1 for core definitions 
Day 16 and 31, respectively. The differences between $\mathrm{N}$ - and $\mathrm{M}$-cores below $4 \mathrm{~cm}$ depth were only significant on Day 16. MN-cores had $\mathrm{TCO}_{2}$ profiles that were intermediate to those of $\mathrm{M}$ - and N-cores, but with profiles and concentrations most similar to and not significantly different from those of M-cores.

Profiles of $\mathrm{NH}_{4}{ }^{+}$showed patterns almost identical to those of $\mathrm{TCO}_{2}$ among treatments and with time (Fig. 4C,D). Concentrations were considerably lower, and C-cores only reached 2.5 and $4.3 \mathrm{mM}$ in the deepest layer on Day 16 and 31, respectively.

Porewater $\mathrm{SO}_{4}{ }^{2-}$ profiles were almost perfect mirror images of the $\mathrm{TCO}_{2}$ profiles (Fig. 4E,F), indicating the importance of sulfate reduction and transport processes for carbon dynamics. The low $\mathrm{SO}_{4}{ }^{2-}$ level observed at the bottom of C-cores on Day 31 corresponds to the low $\mathrm{SR}$ and indicates $\mathrm{SO}_{4}{ }^{2-}$ limitation (Fig. 4F).

\section{Redox}

Redox conditions were clearly affected by Marenzelleria viridis and Nereis diversicolor (Fig. 5). M-cores showed no or only a thin oxidized zone as $\mathrm{Eh}<0 \mathrm{mV}$ was apparent within the upper $0.25 \mathrm{~cm}$. Eh $<-150 \mathrm{mV}$ in these cores was observed at $0.5 \mathrm{~cm}$ depth and reached almost $-200 \mathrm{mV}$ at $5 \mathrm{~cm}$ depth. There was only a slight and insignificant trend for lower Eh in patches with, than in those without, visible Beggiatoa sp. For $\mathrm{N}$-cores, on the other hand, $\mathrm{Eh}<0 \mathrm{mV}$ was first

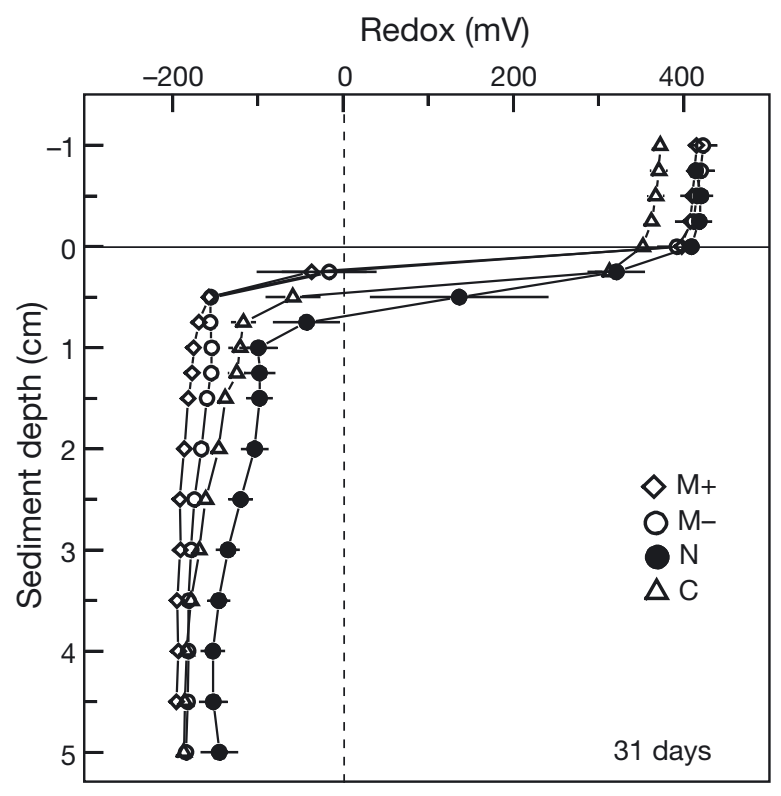

Fig. 5. Vertical redox profiles of upper $5 \mathrm{~cm}$ of $\mathrm{C}-, \mathrm{M}-$, and $\mathrm{N}$ sediment at Day 31. $\mathrm{M}+$ and $\mathrm{M}-$ : profiles within and outside Beggiatoa sp. patches, respectively. Values: mean \pm SE $(n=5$, except $M+$ and $M-$ where $n=3$ ). See Fig. 1 for core definitions recorded at $0.75 \mathrm{~mm}$ depth. These cores had significantly higher Eh than M-cores throughout the measured depth interval and never exhibited values below $-150 \mathrm{mV}$. C-cores showed an intermediate pattern to those of $\mathrm{M}$ - and $\mathrm{N}$-cores, with $\mathrm{Eh} \sim 0 \mathrm{mV}$ between 0.25 and $0.5 \mathrm{~cm}$ depth, and approached the level of M-cores below $3 \mathrm{~cm}$ depth.

\section{DISCUSSION}

\section{Benthic metabolism and reaction pathways}

The presence of Marenzelleria viridis and Nereis diversicolor clearly affects the flux of solutes across the sediment-water interface. It is noteworthy that the absolute rates and enhancement of $\mathrm{O}_{2}$ uptake and $\mathrm{TCO}_{2}$ release were almost similar for the 2 species despite their widely different life habits. The roughly doubling of $\mathrm{O}_{2}$ uptake and $\sim 50 \%$ increased $\mathrm{TCO}_{2}$ release at Day 11 and onwards in faunated compared to control sediment (Fig. 1) is within the range of 45 and $174 \%$ observed previously for homogenized sediment inhabited by $N$. diversicolor (see review by Kristensen 2001). It is important to stress here, though, that the effects of bioturbation on benthic metabolism from our manipulated and transient state laboratory experiment cannot be directly extrapolated to in situ conditions. The enhancement of fluxes we found is higher than generally observed in situ and should instead be considered an increased decomposition capacity caused by the fauna (Kristensen 2001).

The substantially higher $\mathrm{TCO}_{2}$ release than $\mathrm{O}_{2}$ uptake (RQ of 3 to 6) observed in all treatments (Table 1) indicates storage of reducing equivalents and/or dissolution of carbonates within the sediment. Storage of reducing equivalents in the form of sulfide precipitation with, for example, iron can be important, particularly in transient state or manipulated sediments (Ferguson et al. 2003, Gribsholt \& Kristensen 2003, Valdemarsen et al. 2009). Accordingly, the present excess $\mathrm{TCO}_{2}$ efflux relative to a RQ of 1 ranging from 50 to $100 \mathrm{mmol} \mathrm{m} \mathrm{m}^{-2} \mathrm{~d}^{-1}$ corresponds well with the reducing equivalents of sulfide (TRIS, Fig. 3) accumulated within the sediment during the experiment (20 to $80 \mathrm{mmol} \mathrm{m}^{-2} \mathrm{~d}^{-1}$ ). The role of carbonate dissolution can therefore be considered of limited importance in our quartz dominated sandy sediment.

Modification of benthic metabolism by burrow dwelling and irrigating infauna is generally considered a consequence of enhanced microbial activity, altered degradation pathways and the animals own respiration (Aller \& Aller 1998, Glud 2008). Unfortunately, we have no direct measure of the partitioning between enhanced microbial activity and the animals' 
own respiration in the present study. However, several studies have found that the direct contribution of infauna respiration (including Nereis diversicolor) to the total benthic metabolism of bioturbated sediments in general range from 10 to $30 \%$ (Kristensen et al. 1992, Banta et al. 1999, Quintana et al. 2007). The presently observed higher enhancement of benthic metabolism therefore indicates substantial stimulation of microbial activity in the presence of fauna. However, partitioning of degradation pathways estimated from the contribution of SR and denitrification (DENIT) to total benthic metabolism reveals marked differences induced by the 2 polychaete species, particularly at Day 31.

While SR measured in $\mathrm{N}$ - and MN-sediments is similar to rates found by Banta et al. (1999) for sediment with Nereis diversicolor (150 $\left.\mathrm{nmol} \mathrm{cm} \mathrm{cm}^{-3} \mathrm{~d}^{-1}\right)$, SR in M-sediment was ultimately much higher (Fig. 2). It appears that the positive effect of Marenzelleria viridis on SR initiated from below as indicated by a high rate in the 16-18 cm layer at Day 16, and the displacement of the entire profile at Day 31 suggests that the transition was fully implemented within a month. For estimating the contribution of SR to total sediment metabolism in the various treatments, the measured profiles were depth-integrated to $18 \mathrm{~cm}$ depth. These estimates show only slightly higher rates in M-sediment at Day $16\left(27 \mathrm{mmol} \mathrm{S} \mathrm{m}^{-2} \mathrm{~d}^{-1}\right)$ than in the other treatments (19 to $22 \mathrm{mmol} \mathrm{S} \mathrm{m} \mathrm{m}^{-1}$ ). Depthintegrated SR increased considerably in M-sediment at Day 31, reaching $42 \mathrm{mmol} \mathrm{S} \mathrm{m} \mathrm{S}^{-2}$, which is twice as high as in $\mathrm{N}$ - and $\mathrm{MN}$-sediment that remained un- changed with time. The decrease in SR over time and depth in the diffusion controlled C-sediment was probably caused by gradual depletion of sulfate in deeper layers (Fig. 4E,F). Sulfate reduction is generally limited by $\mathrm{SO}_{4}{ }^{2-}$ availability at concentrations $<3 \mathrm{mM}$ (Boudreau \& Westrich 1984). Accordingly, C-sediment at Day 31 exhibited low depth integrated rates $(\sim 11 \mathrm{mmol}$ $\mathrm{m}^{-2} \mathrm{~d}^{-1}$ ).

The role of DENIT can be deduced from simple stoichiometric considerations. If decomposition follows first-order kinetics, the $\mathrm{C}: \mathrm{N}$ ratio of the mineralized organic matter may be ascertained from the vertical steady state porewater profiles of $\mathrm{TCO}_{2}$ and $\mathrm{NH}_{4}{ }^{+}$from anoxic sediments according to Kristensen \& Hansen (1999). Since the solute profiles in the present nonsteady state control cores were affected by diffusion down to 4-6 $\mathrm{cm}$ depth, only this part of the sediment can be considered an open, diffusion dominated zone approaching steady state (Aller \& Mackin 1989). As no sedimentation and compaction occurred, and reaction rates are assumed constant with depth in the upper $6 \mathrm{~cm}$ (Fig. 2), the reaction stoichiometry in this diffusion dominated zone of the sediment can be deduced from a linear regression of a porewater $\mathrm{TCO}_{2}$ versus $\mathrm{NH}_{4}{ }^{+}$plot (Fig. 6). The slope of the regression line is then a proxy for the ratio of $\mathrm{CO}_{2}$ and $\mathrm{NH}_{4}{ }^{+}$production rate or the $\mathrm{C}: \mathrm{N}$ ratio of organic matter being mineralized. Total $\mathrm{NH}_{4}^{+}$production within the sediment is then equal to the measured $\mathrm{TCO}_{2}$ flux divided by the $\mathrm{C}: \mathrm{N}$ ratio (i.e. the regression slopes given in Fig. 6). Due to the limited change in fluxes after Day 11, we assume that the rates measured on Day 18 and 25 are

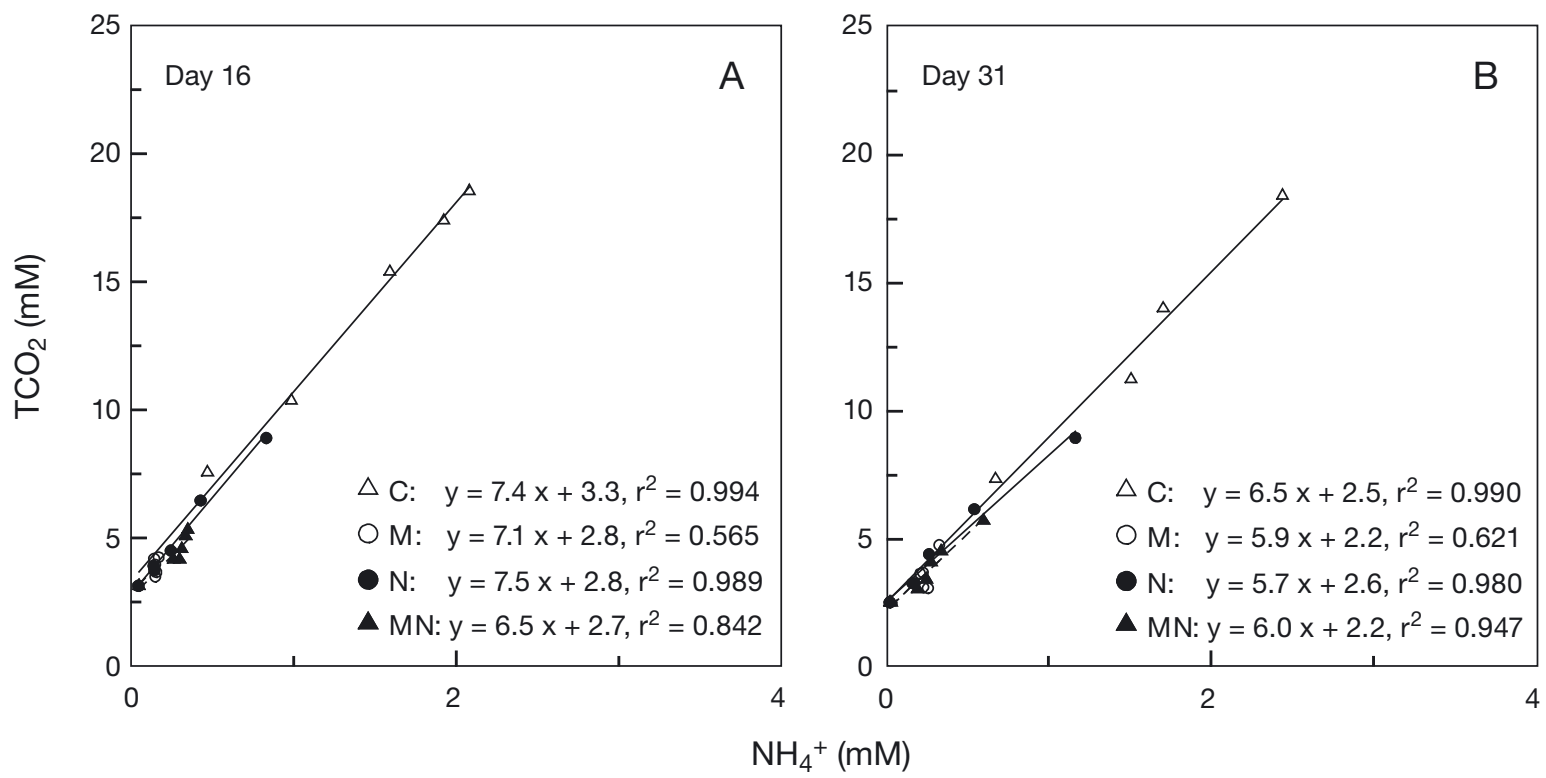

Fig. 6. Relationships between porewater profiles of $\mathrm{NH}_{4}{ }^{+}$and total $\mathrm{CO}_{2}\left(\mathrm{TCO}_{2}\right)$ in $\mathrm{C}-, \mathrm{M}-, \mathrm{N}$ - and MN-sediment at (A) Day 16 and (B) Day 31. Relationships are limited to data from the diffusion controlled upper $6 \mathrm{~cm}$ of the sediment. Lines drawn according to least-squares linear regression and the obtained equations are shown. See Fig. 1 for core definitions 
representative for the sediment conditions on Day 16 and 31, respectively, and vice versa. The slopes or C:N ratios of organic matter mineralization obtained here (5.7 to 7.5) are comparable to those found for other coastal sediments (Kristensen \& Hansen 1999, Weston et al. 2006). DENIT can then be roughly estimated from the missing $\mathrm{N}$ calculated as total $\mathrm{NH}_{4}{ }^{+}$production minus DIN $\left(\mathrm{NH}_{4}{ }^{+}+\mathrm{NO}_{3}{ }^{-}\right)$efflux from the sediment. The obtained rates are comparable for $\mathrm{C}$ - and $\mathrm{N}$ sediments on Day 16 (11 mmol $\left.\mathrm{N} \mathrm{m}^{-2} \mathrm{~d}^{-1}\right)$ and for all treatments on Day 31 (10 to $13 \mathrm{mmol} \mathrm{N} \mathrm{m}^{-2} \mathrm{~d}^{-1}$ ), while somewhat lower rates were evident for $\mathrm{MN}$ - and $\mathrm{M}$ sediments on Day 16 (5 to $7 \mathrm{mmol} \mathrm{N} \mathrm{m}^{-2} \mathrm{~d}^{-1}$ ). These indirect estimates of DENIT are in the high range of rates found previously for near-coastal sediments (Herbert 1999, Bartoli et al. 2000, Rivera-Monroy et al. 2010). It must be emphasized that $C: N$ ratios of organic matter decomposition estimated from porewater regressions are crude and rely on steady state assumptions that may not hold. Another source of error is loss of DIN through assimilation by growing microorganisms (microalgae and bacteria) within the sediment. Accordingly, the estimated rates of DENIT are probably too high and should only be considered a rough measure for comparative purposes in the present artificial sediment system.

Uptake of $\mathrm{NH}_{4}{ }^{+}$by C-sediment kept in darkness for at least $8 \mathrm{~h}$ prior to incubations suggests consumption by e.g. nitrification. The supply of produced $\mathrm{NH}_{4}{ }^{+}$in the deeper sediment layers was not sufficient to meet the nitrification demand in the upper oxic surface sediment, resulting in an uptake from the overlying water. A lack of a corresponding efflux of $\mathrm{NO}_{3}{ }^{-}$was probably caused by DENIT coupled to near-surface nitrification processes (Risgaard-Petersen 2003). The release of $\mathrm{NH}_{4}^{+}$from the sediment in the bioturbated sediment (Table 1) was partly due to increased microbial production of $\mathrm{NH}_{4}{ }^{+}$, and partly excretion by the worms. Thus, several studies have found that various infauna generally are responsible for 20 to $60 \%$ of faunal enhanced efflux of $\mathrm{NH}_{4}{ }^{+}$(Henriksen et al. 1983, Kristensen 1985, Hansen \& Kristensen 1997, Jordan et al. 2009). Furthermore, the measured fluxes of $\mathrm{NH}_{4}{ }^{+}$are similar to those 4 and $9 \mathrm{mmol} \mathrm{m} \mathrm{m}^{-2} \mathrm{~d}^{-1}$ reported earlier for sandy sediment inhabited by Nereis diversicolor (Kristensen 1985, Kristensen \& Hansen 1999, Christensen et al. 2000). Fluxes of $\mathrm{NH}_{4}{ }^{+}$for sediment inhabited by Marenzelleria spp. are known to range from 1.6 to $13 \mathrm{mmol} \mathrm{m}^{-2}$ $\mathrm{d}^{-1}$ (Karlson et al. 2005, Viitasalo-Frösén et al. 2009).
Partitioning of reaction pathways based on the above estimates shows that SR (converted to C-units by multiplying by 2) was always the most important anaerobic carbon mineralization process accounting for at least 33 to $75 \%$. This is a minimum estimate because the deepest $5 \mathrm{~cm}$ of the sediment, where SR was not measured, is unaccounted for. Accordingly, DENIT (converted to C-units by multiplying by 1.25) was responsible for no more than 7 to $25 \%$ of $\mathrm{TCO}_{2}$ release. The group 'OTHER' in Table 2 accounted mostly for 12 to $52 \%$, which primarily represents aerobic respiration because $\mathrm{Fe}$ and $\mathrm{Mn}$ concentrations are relatively low in sandy sediments from Odense Fjord (Kristiansen et al. 2002). Aerobic respiration that includes the fauna contribution corresponds roughly to or is lower than the measured rates of $\mathrm{O}_{2}$ uptake, and the low value for particularly $\mathrm{M}$-sediment at Day 31 leaves room for sulfide oxidation by Beggiatoa sp. The estimated partitioning is comparable to those reported from other coastal sediments (Jørgensen \& Sørensen 1985, Canfield et al. 1993, Fennel et al. 2009) although considerable variation occurs among environments (Rysgaard et al. 2001)

The pronounced stimulation of sulfate reduction by Marenzelleria viridis has wider biogeochemical implications. The low redox and presence of Beggiatoa sp. at the sediment surface of $\mathrm{M}$-sediment, indicates that a fraction of the produced sulfide escaped the iron trap in the sediment and moved upward towards the sediment-water interface by diffusion (Kristiansen et al. 2002) and $M$. viridis irrigation (see below). Consequently, the escaped sulfide in M-sediment was, to a larger extent than in the other treatments, oxidized or

Table 2. Marenzelleria viridis and Nereis diversicolor. Partitioning of reaction pathways in C-, M-, N-, and MN-cores at Day 16 and 31. $\mathrm{TCO}_{2}$ flux: total carbon oxidation in $23 \mathrm{~cm}$ deep sediment column. Since no $\mathrm{TCO}_{2}$ flux was measured on Day 16 and 31, results from Day 18 and 25 are used instead, assuming limited change over few days late in the experiment. SR: sulfate reduction (only to $18 \mathrm{~cm}$ depth); DENIT: denitrification; OTHER: combined aerobic, Fe and $\mathrm{Mn}$ respiration. Rates given as $\mathrm{mmol} \mathrm{C} \mathrm{m}^{-2} \mathrm{~d}^{-1}$ and values in parentheses are percent of total. See text for explanation of calculations. See Table 1 for core abbreviations

\begin{tabular}{|lcccc|}
\hline Reaction & \multicolumn{1}{c}{$\mathrm{C}$} & $\mathrm{M}$ & $\mathrm{N}$ & $\mathrm{MN}$ \\
\hline Day 16 & & & & \\
$\mathrm{TCO}_{2}$ flux & 64.5 & 100.9 & 98.8 & 89.5 \\
$\mathrm{SR}$ & $37.2(58)$ & $54.6(54)$ & $44.6(45)$ & $44.8(50)$ \\
$\mathrm{DENIT}$ & $13.8(21)$ & $8.8(9)$ & $13.3(14)$ & $6.3(7)$ \\
OTHER & $13.5(21)$ & $37.5(37)$ & $40.9(41)$ & $38.4(43)$ \\
& & & & \\
Day 31 & & 110.9 & 100.9 & 109.6 \\
$\mathrm{TCO}_{2}$ flux & 64.2 & $83.6(75)$ & $42.8(42)$ & $41.0(37)$ \\
$\mathrm{SR}$ & $21.4(33)$ & $13.9(13)$ & $14.4(14)$ & $12.0(11)$ \\
DENIT & $16.0(25)$ & $13.4(12)$ & $43.7(43)$ & $56.6(52)$ \\
OTHER & $26.8(42)$ & &
\end{tabular}


released to the overlying water column (Kristensen et al. 2000). It is also remarkable that MN-sediment containing a mixture of Nereis diversicolor and $M$. viridis had a partitioning of reaction pathways similar to the $\mathrm{N}$-sediment (Table 2). Higher ventilation activities by $N$. diversicolor than $M$. viridis (Quintana et al. 2011) were apparently responsible for more oxidized conditions in the MN-sediment, which may have hampered sulfate reduction as also noted by Banta et al. (1999). The higher redox in $N$. diversicolor than $M$. viridis sediment (Fig. 5) was visually evident by a thicker oxidized halo around burrows of the former.

The enhancement of SR by the presence of Marenzelleria viridis is, however, puzzling. There is no doubt that this polychaete irrigates its burrow, and as such must introduce $\mathrm{O}_{2}$ and $\mathrm{SO}_{4}{ }^{2-}$ into the sediment (Quintana et al. 2011), which may either hamper or stimulate SR. Nevertheless, redox was lowered and SR was more than doubled in M-sediment compared with the other treatments. Besides the elevated redox in the presence of Nereis diversicolor and sulfate depletion in C-sediment, the relatively high SR in M-sediment may be explained by translocation of labile organic matter from the surface to deeper layers through M.viridis' feeding activities. This species is known to be a surface deposit-feeder that collects detritus by its palps (Dauer 1997). If some of this detritus enters the burrow, it may, together with faeces deposited inside burrows and mucus secretions along burrow walls (Dauer et al. 1981, Zettler et al. 1994), provide sulfate reducers with reactive organic carbon. Furthermore, deep irrigation by $M$. viridis ensures that $\mathrm{SO}_{4}{ }^{2-}$ is available to all anoxic sediment layers. However, there is at present no clear evidence for the cause of the surprising microbial response in $\mathrm{M}$-sediment and further studies are required to elucidate this enigma.

\section{Solute distribution and irrigation}

The considerably lower concentrations of porewater $\mathrm{TCO}_{2}$ and $\mathrm{NH}_{4}{ }^{+}$in faunated than defaunated sediment was caused by enhanced transport due to irrigation (Shull et al. 2009). The effect appeared most pronounced in the presence of Marenzelleria viridis. Despite the higher production of $\mathrm{TCO}_{2}$ and $\mathrm{NH}_{4}{ }^{+}$in faunated sediment due to stimulated microbial activity and worm respiration/excretion, the enhanced irrigation transport caused by faunal ventilation maintained concentrations lower than in the diffusion controlled C-sediment (Fig. 4). The opposite arguments are valid for $\mathrm{SO}_{4}{ }^{2-}$, which was consumed by sulfate reduction in the anoxic sediment and supplied from the overlying water by diffusion and irrigation transport. Both Nereis diversicolor and $M$. viridis have the capacity to prevent $\mathrm{SO}_{4}{ }^{2-}$ depletion throughout the experimental period, as observed in the deeper part of the C-sediment.

The deep burrowing Marenzelleria viridis always maintained porewater solutes close to the overlying water level in the entire sediment column, whereas Nereis diversicolor only managed an increased transport within its burrowing depth of $\sim 8 \mathrm{~cm}$. MNsediment did not appear as a true mixture of $\mathrm{M}$ - and $\mathrm{N}$-sediments, but was more affected by $M$. viridis than $N$. diversicolor in terms of porewater profiles. This phenomenon is a consequence of their different life habits. $M$. viridis normally digs burrows down to depths of $30 \mathrm{~cm}$ or more, whereas $N$. diversicolor is most commonly restricted to depths $>10 \mathrm{~cm}$ (Zettler et al. 1994), which is consistent with our observations. Although the ventilation of $N$. diversicolor is $\sim 10$ times faster than that of a similar sized $M$. viridis (Christensen et al. 2000, Quintana et al. 2011), the effects of deep irrigation by $M$. viridis on porewater transport appear to be much stronger. Similarly, MermillodBlondin et al. (2005) found that $N$. diversicolor hides the effect of shallow burying bivalves and crustaceans on porewater profiles due to its stronger and deeper irrigation.

The irrigation effect of Marenzelleria viridis is demonstrated clearly from the empirical ventilationporewater relationships observed by Christensen et al. (2000). They measured ventilation of various species of Nereis under different conditions and found that the irrigation-induced depletion of porewater $\mathrm{TCO}_{2}$ in the upper diffusion-dominated zone of the sediment related logarithmically to area-specific ventilation $\left(\mathrm{l} \mathrm{m}^{-2} \mathrm{~d}^{-1}\right)$ according to: Relative $\mathrm{TCO}_{2}$ depletion $=$ $-0.122 \ln$ (ventilation) +0.99 , with $\mathrm{r}^{2}=0.99$.

The relative depletion of porewater $\mathrm{TCO}_{2}$ is defined as the slope of a linear relationship between porewater profiles in faunated and defaunated sediment (Fig. 7). Slopes $<1$ indicate a faster removal of $\mathrm{TCO}_{2}$ due to irrigation transport than by molecular diffusion.

The predicted area-specific ventilation based on the $\mathrm{TCO}_{2}$ depletion relationships in the present $\mathrm{N}$-sediment (Fig. 7), normalized to a Nereis diversicolor density of $600 \mathrm{~m}^{-2}$, is 870 and $590 \mathrm{l} \mathrm{m}^{-2} \mathrm{~d}^{-1}$ at Day 16 and 31, respectively, which is remarkably similar to the $754 \mathrm{l} \mathrm{m}^{-2} \mathrm{~d}^{-1}$ measured for the same density of non-suspension feeding $N$. diversicolor by Christensen et al. (2000). However, the predicted area-specific ventilation of 1900 to $2000 \mathrm{l} \mathrm{m}^{-2} \mathrm{~d}^{-1}$ by a population of Marenzelleria viridis $\left(600 \mathrm{~m}^{-2}\right)$ exceeds by more than one order of magnitude the 50 to $100 \mathrm{l} \mathrm{m}^{-2} \mathrm{~d}^{-1}$ estimated from directly measured ventilation by this species (Quintana et al. 2011). The discrepancy must be caused by different irrigation efficiency of the 2 species. The high ventilation of $N$. diversicolor creates a 


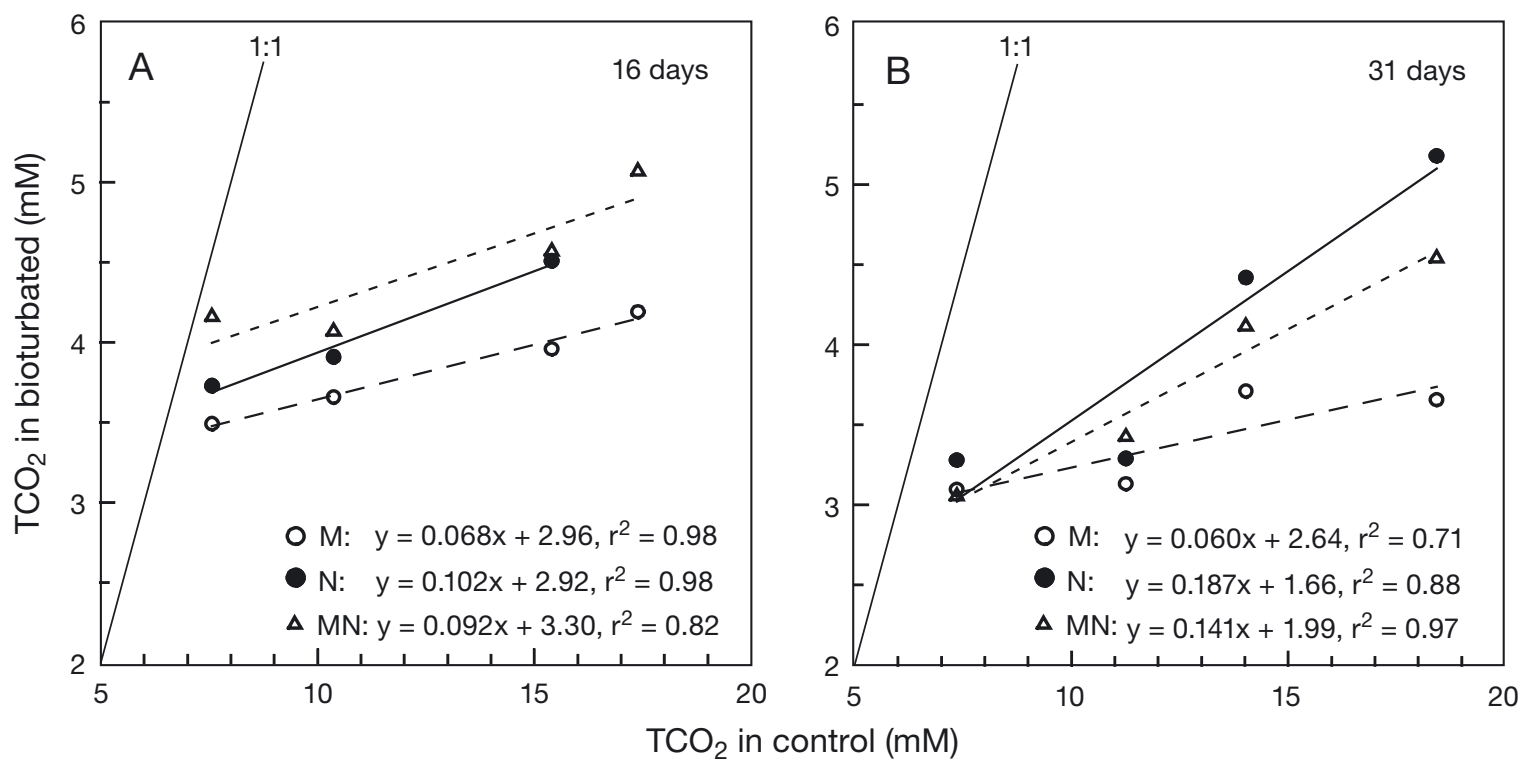

Fig. 7. Relationship between porewater total $\mathrm{CO}_{2}\left(\mathrm{TCO}_{2}\right)$ in control $(\mathrm{C})$ sediment and the corresponding faunated sediments $(\mathrm{M}$, $\mathrm{N}$ and $\mathrm{MN}$ ) at Days (A) 16 and (B) 31. Lines drawn according to least-squares linear regression and the obtained equations are shown. The 1:1 lines shown for comparison. See Fig. 1 for core definitions

rapid transport of water through the U-shaped burrow and back to the overlying water with only radial diffusive and limited advective porewater solute exchange (Davey \& Watson 1995, Kristensen \& Hansen 1999). $M$. viridis, on the other hand, lives in deep and blindended L- or J-shaped burrows. Some of the water ventilated into the burrow must therefore percolate up through the sediment, carrying solutes efficiently back to the overlying water (Quintana et al. 2011). The irrigation mechanism of $M$. viridis, in principle, functions as for the lugworm Arenicola marina (Timmermann et al. 2002, Meysman et al. 2005), except that the ventilated water percolates into the sediment along the entire shaft of $M$. viridis burrows and not only through the dead-end (Quintana et al. 2011). M. viridis certainly irrigates porewater solutes much more efficiently than $N$. diversicolor despite an order of magnitude lower ventilation: an effect that is greatly amplified by the much greater depth of sediment influenced by $M$. viridis irrigation.

\section{Ecological consequences of replacing Nereis diversicolor with Marenzelleria viridis}

A replacement of the native Nereis diversicolor with the invasive Marenzelleria viridis as the dominant burrow-dwelling polychaete in shallow coastal areas, which is a current concern, may have serious biogeochemical and ecological implications. As predicted by our hypotheses, activities of the deep burrowing $M$. viridis alter the balance of biogeochemical path- ways by increasing sulfate reduction at the expense of aerobic processes, and its stronger porewater irrigation enhances the transport of porewater metabolites, such as sulfide, towards the sediment-water interface. The presence of near-surface sulfide in $M$. viridis inhabited sandflats of Odense Fjord is visually evident (even from Google Earth) as a purple coloration of the sediment surface due to purple sulfur bacteria (authors' pers. obs.). Consequently, organisms tolerant to and dependent on sulfide (e.g. sulfur oxidizing bacteria and opportunistic polychaetes) will be favored at the expense of sensitive species (e.g. large polychaetes and crustaceans) (Levin et al. 2009). Actually, M. viridis itself is highly tolerant to low oxygen and high sulfide (Schiedek 1997). Such a shift in species composition yields altered trophic structures and energy flow pathways, as previously observed for other anthropogenically induced hypoxia events (Karlson et al. 2002). Although we found no change in overall rates of benthic metabolism and inorganic nitrogen dynamics when $M$. viridis replaced $N$. diversicolor in our shortterm experiment, it is likely that the more reduced conditions over longer time scales will hamper carbon oxidation and enhance the release of inorganic nitrogen and phosphorus to the overlying water (Kristensen \& Holmer 2001). The species composition, functioning and stability of the ecosystem may therefore be in jeopardy if the well-oxidized conditions maintained in the upper sediment layers by $N$. diversicolor through its strong ventilation is replaced with the more sluggish ventilation, but much stronger and deeper irrigation, of $M$. viridis. 
Acknowledgements. Our gratitude is due to B. Christensen and C. Lohmann for skilful technical assistance during the laboratory work. This research was supported by the Danish Research Agency (contract \#272-08-0577 and \#09-071369).

\section{LITERATURE CITED}

Aller RC (1982) The effects of macrobenthos on chemical properties of marine sediment and overlying water. In: McCall PL, Tevesz MJS (eds) Animal-sediment relations. Plenum Press, New York, NY

Aller RC (2001) Transport and reactions in the bioirrigated zone. In: Boudreau BP, Jørgensen BB (eds) The benthic boundary layer: transport processes and biogeochemistry. Oxford University Press, Oxford

Aller RC, Aller JY (1998) The effect of biogenic irrigation intensity and solute exchange on diagenetic reaction rates in marine sediments. J Mar Res 56:905-936

Aller RC, Mackin JE (1989) Open-incubation, diffusion methods for measuring solute reaction rates in sediments. J Mar Res 47:411-440

Armstrong FA, Stearns CR, Strickland JD (1967) The measurement of upwelling and subsequent biological processes by means of the Technicon Autoanalyzer and associated equipment. Deep-Sea Res 14:381-389

Bale AJ, Kenny AJ (2005) Sediment analysis and seabed characterization. In: Eleftheriou A, McIntyre A (eds) Methods for the study of marine benthos, 3rd edn. Blackwell Science, Oxford

Banta GT, Holmer M, Jensen MH, Kristensen E (1999) Effects of two polychaete worms, Nereis diversicolor and Arenicola marina, on aerobic and anaerobic decomposition in sandy marine sediment. Aquat Microb Ecol 19:189-204

Bartoli M, Nizzoli D, Welsh DT, Viaroli P (2000) Short-term influence of recolonisation by the polycheate worm Nereis succinea on oxygen and nitrogen fluxes and denitrification: a microcosm simulation. Hydrobiologia 431:165-174

Bastrop R, Blank M (2006) Multiple invasions: a polychaete genus enters the Baltic Sea. Biol Invasions 8:1195-1200

Blank M, Laine AO, Jürss K, Bastrop R (2008) Molecular identification key based on PCR/RFLP for three polychaete sibling species of the genus Marenzelleria, and the species' current distribution in the Baltic Sea. Helgol Mar Res 62:129-141

Boudreau BP, Westrich JT (1984) The dependence of bacterial sulfate reduction on sulfate concentration in marine sediments. Geochim Cosmochim Acta 48:2503-2516

Bower CE, Holm-Hansen T (1980) A salicylate-hypochlorite method for determining ammonia in seawater. Can J Fish Aquat Sci 37:794-798

> Canfield DE, Thamdrup B, Hansen JW (1993) The anaerobic degradation of organic matter in Danish coastal sediments: iron reduction, manganese reduction and sulfate reduction. Geochim Cosmochim Acta 57:3867-3883

> Christensen B, Vedel A, Kristensen E (2000) Carbon and nitrogen fluxes in sediment inhabited by suspensionfeeding (Nereis diversicolor) and non-suspension-feeding (N. virens) polychaetes. Mar Ecol Prog Ser 192:203-217

Cline JD (1969) Spectrophotometric determination of hydrogen sulfide in natural waters. Limnol Oceanogr 14: $454-458$

Dauer DM (1997) Functional morphology and feeding behavior of Marenzelleria viridis (Polychaeta: Spionidae). Bull Mar Sci 60:512-516

Dauer DM, Maybury CA, Ewing RM (1981) Feeding behavior and general ecology of several spionid polychaetes from the Chesapeake Bay. J Exp Mar Biol Ecol 54:21-38

Davey JT, Watson PG (1995) The activity of Nereis diversicolor (Polychaeta) and its impact on nutrient fluxes in estuarine waters. Ophelia 41:57-70

Esselink P, Zwarts L (1989) Seasonal trend in burrow depth and tidal variation in feeding-activity of Nereis diversicolor. Mar Ecol Prog Ser 56:243-254

Essink K, Kleef HL (1988) Marenzelleria viridis (Verrill, 1873) (Polychaeta: Spionidae): a new record from the Ems Estuary (The Netherlands/Federal Republic of Germany). Zool Bijdr 38:1-13

Essink K, Kleef HL (1993) Distribution and life cycle of the north american spionid polychaete Marenzelleria viridis (Verrill, 1873) in the Ems estuary. Neth J Aquat Ecol 27: 237-246

Fennel K, Brady D, DiToro D, Fulweiler RW and others (2009) Modeling denitrification in aquatic sediments. Biogeochemistry 93:159-178

Ferguson AJP, Eyre BD, Gay JM (2003) Organic matter and benthic metabolism in euphotic sediments along shallow sub-tropical estuaries, northern New South Wales, Australia. Aquat Microb Ecol 33:137-154

Fossing H, Jørgensen BB (1989) Measurement of bacterial sulfate reduction in sediments: evaluation of a single-step chromium reduction method. Biogeochemistry 8:205-222

Fyns Amt (2003) Kystvande 2002. Vandmiljøovervågning. Natur- og Vandmiljøafdelingen, Fyns Amt, Odense

George JD (1966) Reproduction and early development of the spionid polychaete, Scolecolepides viridis (Verril). Biol Bull 130:76-93

Glud RN (2008) Oxygen dynamics of marine sediments. Mar Biol Res 4:243-289

> Gribsholt B, Kristensen E (2003) Benthic metabolism and sulfur cycling along an inundation gradient in a tidal Spartina anglica salt marsh. Limnol Oceanogr 48:2151-2162

Hall POJ, Aller RC (1992) Rapid, small-volume, flow injection analysis for $\Sigma \mathrm{CO}_{2}$ and $\mathrm{NH}_{4}{ }^{+}$in marine and freshwaters. Limnol Oceanogr 37:1113-1119

> Hansen K, Kristensen E (1997) Impact of macrofaunal recolonization on benthic metabolism and nutrient fluxes in a shallow marine sediment previously overgrown with macroalgal mats. Estuar Coast Shelf Sci 45:613-628

Hansen K, Kristensen E (1998) The impact of the polychaete Nereis diversicolor and enrichment with macroalgal (Chaetomorpha linum) detritus on benthic metabolism and nutrient dynamics in organic-poor and organic-rich sediment. J Exp Mar Biol Ecol 231:201-223

Henriksen K, Rasmussen MB, Jensen A (1983) Effect of bioturbation on microbial nitrogen transformations in the sediment and fluxes of ammonium and nitrate to the overlaying water. Ecol Bull 35:193-205

- Herbert RA (1999) Nitrogen cycling in coastal marine ecosystems. FEMS Microbiol Rev 23:563-590

> Hietanen S, Laine AO, Lukkari K (2007) The complex effects of the invasive polychaetes Marenzelleria spp. on benthic nutrient dynamics. J Exp Mar Biol Ecol 352:89-102

> Jahnke R, Richards M, Nelson J, Robertson C, Rao A, Jahnke D (2005) Organic matter remineralization and porewater exchange rates in permeable South Atlantic Bight continental shelf sediments. Cont Shelf Res 25:1433-1452

> Jordan MA, Welsh DT, Dunn RJK, Teasdale PR (2009) Influence of Trypaea australiensis population density on benthic metabolism and nitrogen dynamics in sandy estuarine sediment: a mesocosm simulation. J Sea Res 61: $144-152$ 
Jørgensen BB, Boudreau BP (2001) Diagenesis and sediment-water exchange. In: Boudreau BP, Jørgensen BB (eds) The benthic boundary layer: transport processes and biogeochemistry. Oxford University Press, Oxford, p 211-244

Jørgensen BB, Sørensen J (1985) Seasonal cycles of $\mathrm{O}_{2}, \mathrm{NO}_{3}^{-}$ and $\mathrm{SO}_{4}{ }^{2-}$ reduction in estuarine sediments: the significance of an $\mathrm{NO}_{3}{ }^{-}$maximum in spring. Mar Ecol Prog Ser 24:65-74

Karlson K, Rosenberg R, Bonsdorff E (2002) Temporal and spatial large-scale effects of eutrophication and oxygen deficiency on benthic fauna in Scandinavian and Baltic waters: a review. Oceanogr Mar Biol Annu Rev 40: 427-489

Karlson K, Hulth S, Ringdahl K, Rosenberg R (2005) Experimental recolonisation of Baltic Sea reduced sediments: survival of benthic macrofauna and effects on nutrient cycling. Mar Ecol Prog Ser 294:35-49

Kotta J, Kotta I, Simm M, Lankov A, Lauringson V, Pollumae A, Ojaveer H (2006) Ecological consequences of biological invasions: three invertebrate case studies in the northeastern Baltic Sea. Helgol Mar Res 60:106-112

Kristensen E (1985) Oxygen and inorganic nitrogen exchange in a Nereis virens (Polychaeta) bioturbated sedimentwater system. J Coast Res 1:109-116

Kristensen E (2000) Organic matter diagenesis at the oxic/ anoxic interface in coastal marine sediments, with emphasis on the role of burrowing animals. Hydrobiologia 426: $1-24$

Kristensen E (2001) Impact of polychaetes (Nereis spp. and Arenicola marina) on carbon biogeochemistry in coastal marine sediments. Geochem Trans 2:92-103

Kristensen E, Andersen FØ (1987) Determination of organic carbon in marine sediments: comparison of two CHNanalyzer methods. J Exp Mar Biol Ecol 109:15-23

Kristensen E, Hansen K (1999) Transport of carbon dioxide and ammonium in bioturbated (Nereis diversicolor) coastal, marine sediments. Biogeochemistry 45:147-168

Kristensen E, Holmer M (2001) Decomposition of plant materials in marine sediment exposed to different electron acceptors $\left(\mathrm{O}_{2}, \mathrm{NO}_{3}{ }^{-}\right.$and $\left.\mathrm{SO}_{4}{ }^{2-}\right)$, with emphasis on substrate origin, degradation kinetics and the role of bioturbation. Geochim Cosmochim Acta 65:419-434

Kristensen E, Kostka JE (2005) Macrofaunal burrows and irrigation in marine sediment: microbiological and biogeochemical interactions. In: Kristensen E, Haese RR, Kostka JE (eds) Interactions between macro- and microorganisms in marine sediments. American Geophysical Union, Washington, DC, p 125-157

Kristensen E, Mikkelsen OL (2003) Impact of the burrowdwelling polychaete Nereis diversicolor on degradation of fresh and aged macroalgal detritus in coastal marine sediment. Mar Ecol Prog Ser 265:141-153

Kristensen E, Andersen FØ, Blackburn TH (1992) Effects of benthic macrofauna and temperature on degradation of macroalgal detritus: the fate of organic carbon. Limnol Oceanogr 37:1404-1419

Kristensen E, Bodenbender J, Jensen MH, Rennenberg $\mathrm{H}$, Jensen KM (2000) Sulfur cycling of intertidal Wadden Sea sediments (Konigshafen, Island of Sylt, Germany): sulfate reduction and sulfur gas emission. J Sea Res 43: 93-104

- Kristiansen KD, Kristensen E, Jensen MH (2002) The influence of water column hypoxia on the behaviour of manganese and iron in sandy coastal marine sediment. Estuar Coast Shelf Sci 55:645-654
Levin LA, Ekau W, Gooday AJ, Jorisson F and others (2009) Effects of natural and human-induced hypoxia on coastal benthos. Biogeosciences 6:2063-2098

Maltagliati F, Massaro L, Cossu P, Castelli A (2006) Morphological differentiation in the ragworm, Hediste diversicolor (Polychaeta, Nereididae), as revealed by variation of paragnath number and distribution. Ital J Zool 73:255-262

Martin WR, Banta GT (1992) The measurement of sediment irrigation rates: a comparison of the $\mathrm{Br}^{-}$tracer and ${ }^{222} \mathrm{Rn} /$ ${ }^{226} \mathrm{Ra}$ disequilibrium techniques. J Mar Res 50:125-154

McLusky DS, Hull SC, Elliott M (1993) Variations in the intertidal and subtidal macrofauna and sediments along a salinity gradient in the upper Forth Estuary. Neth J Aquat Ecol 27:101-109

> Meile C, Van Cappellen P (2003) Global estimates of enhanced solute transport in marine sediments. Limnol Oceanogr 48:777-786

Mermillod-Blondin F, Francois-Carcaillet F, Rosenberg R (2005) Biodiversity of benthic invertebrates and organic matter processing in shallow marine sediments: an experimental study. J Exp Mar Biol Ecol 315:187-209

> Meysman FJR, Galaktionov OS, Middelburg JJ (2005) Irrigation patterns in permeable sediments induced by burrow ventilation: a case study of Arenicola marina. Mar Ecol Prog Ser 303:195-212

> Meysman FJR, Galaktionov ES, Gribsholt B, Middelburg JJ (2006) Bioirrigation in permeable sediments: advective pore-water transport induced by burrow ventilation. Limnol Oceanogr 51:142-156

Nielsen OI, Gribsholt B, Kristensen E, Revsbech NP (2004) Microscale distribution of oxygen and nitrate in sediment inhabited by Nereis diversicolor: spatial patterns and estimated reaction rates. Aquat Microb Ecol 34:23-32

> Papaspyrou S, Gregersen T, Kristensen E, Christensen B, Cox RP (2006) Microbial reaction rates and bacterial communities in sediment surrounding burrows of two nereidid polychaetes (Nereis diversicolor and $N$. virens). Mar Biol 148:541-550

- Papaspyrou S, Kristensen E, Christensen B (2007) Arenicola marina (Polychaeta) and organic matter mineralisation in sandy marine sediments: in situ and microcosm comparison. Estuar Coast Shelf Sci 72:213-222

Parsons TR, Maita Y, Lalli CM (1984) A manual of chemical and biological methods for seawater analysis. Pergamon Press, Oxford

> Quintana CO, Tang M, Kristensen E (2007) Simultaneous study of particle reworking, irrigation transport and reaction rates in sediment bioturbated by the polychaetes Heteromastus and Marenzelleria. J Exp Mar Biol Ecol 352:392-406

Quintana CO, Hansen T, Delefosse M, Banta GT, Kristensen E (2011) Burrow ventilation and associated porewater irrigation by the polychaete Marenzelleria viridis. J Exp Mar Biol Ecol 397:179-187

Riisgård HU (1991) Suspension feeding in the polychaete Nereis diversicolor. Mar Ecol Prog Ser 70:29-37

> Risgaard-Petersen N (2003) Coupled nitrification-denitrification in autotrophic and heterotrophic estuarine sediments: on the influence of benthic microalgae. Limnol Oceanogr 48:93-105

> Rivera-Monroy VH, Lenaker P, Twilley RR, Delaune RD and others (2010) Denitrification in coastal Louisiana: a spatial assessment and research needs. J Sea Res 63:157-172

Rysgaard S, Fossing H, Jensen MM (2001) Organic matter degradation through oxygen respiration, denitrification, and manganese, iron, and sulfate reduction in marine 
sediments (the Kattegat and the Skagerrak). Ophelia 55: 77-91

Schiedek D (1997) Marenzelleria viridis (Verrill, 1873) (Polychaeta), a new benthic species within European coastal waters. Some metabolic features. J Exp Mar Biol Ecol 211:85-101

Shull DH, Benoit JM, Wojcik C, Senning JR (2009) Infaunal burrow ventilation and pore-water transport in muddy sediments. Estuar Coast Shelf Sci 83:277-286

Sikorski AV, Bick A (2004) Revision of Marenzelleria Mesnil, 1896 (Spionidae, Polychaeta). Sarsia 89:253-275

> Timmermann K, Christensen JH, Banta GT (2002) Modeling of advective solute transport in sandy sediments inhabited by the lugworm Arenicola marina. J Mar Res 60:151-169

Valdemarsen T, Holmer M, Kristensen E (2009) Metabolic threshold and sulfide-buffering in diffusion controlled

Editorial responsibility: Hans Heinrich Janssen, Oldendorf/Luhe, Germany marine sediments impacted by continuous organic enrichment. Biogeochemistry 95:335-353

- Viitasalo-Frösén S, Laine AO, Lehtiniemi M (2009) Habitat modification mediated by motile surface stirrers versus semi-motile burrowers: potential for a positive feedback mechanism in a eutrophied ecosystem. Mar Ecol Prog Ser 376:21-32

Weston NB, Porubsky WP, Samarkin VA, Erickson M, Macavoy SE, Joye SB (2006) Porewater stoichiometry of terminal metabolic products, sulfate, and dissolved organic carbon and nitrogen in estuarine intertidal creekbank sediments. Biogeochemistry 77:375-408

Zettler ML, Bochert R, Bick A (1994) Röhrenbau und Vertikalverteilung von Marenzelleria viridis (Polychaeta: Spionidae) in einem inneren Küstengewässer der südlichen Ostsee. Rostock Meeresbiol Beitr 2:215-225

Submitted: August 25, 2010; Accepted: December 20, 2010 Proofs received from author(s): March 4, 2011 